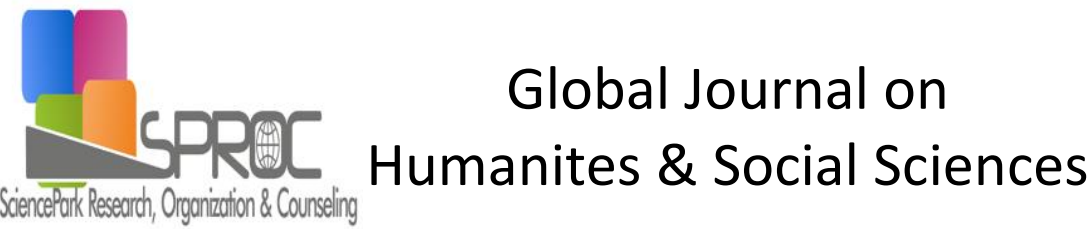

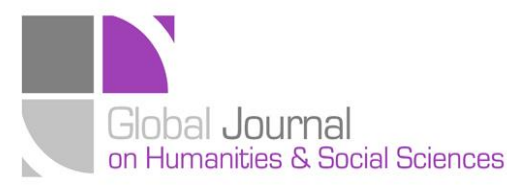

Vol 3 (2016) 487-497

Selected Paper of 4th World Conference on Design and Arts, (DAE-2015)

26-28 June 2015, St.Petersburg Christan University, St. Petersburg, Russia.

\section{Arts and design education for sustainable development}

Vedat Özsoy*, TOBB University of Economics and Technolgy, Sogutozu Cad. No: 43, Ankara 06560, Turkey.

\section{Suggested Citation:}

Özsoy, V. (2016). Arts and Design Education for Sustainable Development, Global Journal on Humanites \& Social Sciences. [Online]. 03, pp 487-497. Available from: http://sproc.org/ojs/index.php/pntsbs

Received January 10, 2015; revised March 10, 2015; accepted April 20, 2015.

Selection and peer review under responsibility of Prof. Dr. Milan Matijevic.

(C)2016 SciencePark Research, Organization \& Counseling. All rights reserved.

\begin{abstract}
The UN General Assembly realized in 1983 that there was a heavy deterioration of the human environment and natural resources, and established the World Commission on Environment and Development (WCED). WCED's mission was to unite countries to pursue sustainable development together. This commission prepared a report called as "Our Common Future" in October 1987. The focus in the report was that the perspectives of society and nature are equal to that of economy.

Countries' economic and social development being sustainable, preventing global climate changes and natural disasters are directly proportionate to education strategies' involving sustainability. Sustainability education is a model that aims to support the learners to become responsible citizens who struggle for a more sustainable world with their knowledge, skills, values and mental abilities. UNESCO indicates that "Education for Sustainable Development" allows every human being to acquire the knowledge, skills, attitudes and values necessary to shape a sustainable future.

Art and design education has a multi-directional content for sustainable development ideals. For example, aesthetic sensitivity and critical thinking which are in the nature of art and design subjects, help students grow as individuals who are environment and ecosystem-sensitive. Sustainability of art and design education could be seen in two-directions. The first side is to keep students away from any kind of violence by providing them with sensitivity and empathy as well as help them develop respect for society and environment. In this way, students gain susceptibility and eagerness to protect ecosystem and live in the limits of nature. The second side is the sustainability projects carried out by students and instructors in art and design lessons. These are applications especially to clarify that a sustainable environment, nature and ecosystem is important for a sustainable life. This study includes some practical examples about the second side.
\end{abstract}

Keywords: Sustainability, art and design education.

* ADDRESS FOR CORRESPONDENCE: Vedat Özsoy, TOBB University of Economics and Technology, Sogutozu Cad. No: 43, Ankara 06560, Turkey.E-mail address: vozsoy@gmail.com / Tel.: +90-533-488-6171 
Özsoy, V. (2016). Arts and Design Education for Sustainable Development, Global Journal on Humanites \& Social Sciences. [Online]. 03, pp 487-497. Available from: http://sproc.org/ojs/index.php/pntsbs

\section{Introduction}

TEMA, "Turkish Foundation for Combating Soil Erosion, for Reforestation and the Protection of Natural Habitats" has a success story from Turkey concerning environment and ecosystem. Two earth lovers, "Father Soil" Hayrettin Karaca and "Father Leaf" A. Nihat Gökyiğit, who are named as these by Turkish people, founded TEMA foundation together in 1992 (Fig.1). They aimed to bring attention to the dangers of erosion and desertification in Turkey. Their goal was to ensure that this became a government policy. The slogan of TEMA "Don't let Turkey become a desert" influenced many people. The first "Earth Summit", which was held in June 1992 in Rio de Janerio in Brazil, was a milestone for the governments to accept ecosystem destruction humans had been causing and also for putting forward the efforts against it by globalizing them. This summit also played a great role in providing civil society to appear as a strong element. With its slogan "Earth is life", TEMA was founded only few months after this summit (TEMA, 2015). TEMA, with its sustainable life principle, works as a nongovernmental organization (NGO) that attaches importance to scientific studies to protect natural assets especially soil (Figure 1). The campaign that TEMA foundation follows for a sustainable ecosystem and a sustainable world for every living creature is also the base for a sustainable development. A sustainable ecosystem, a sustainable environment, a sustainable development and a sustainable education. I believe, now, we need to mention about the concept of sustainability which has been used widely in the first years of this millennium.
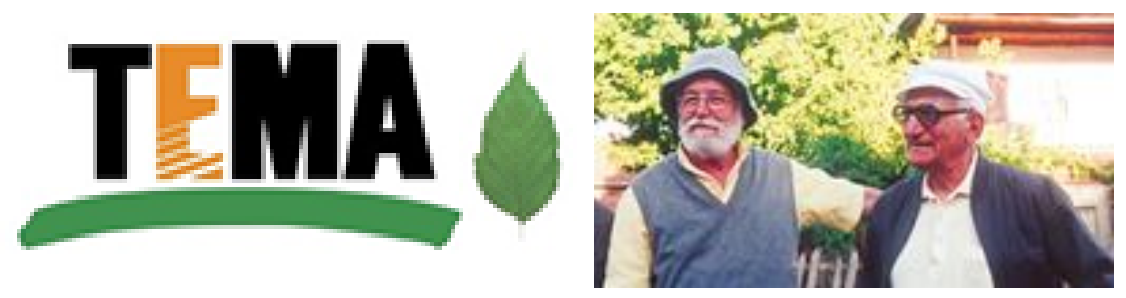

Fig. 1. TEMA, Hayrettin Karaca and A. Nihat Gökyiğit.

\section{What is sustainability?}

Sustainability, whose dictionary definition is "the ability to be sustained, supported, upheld, or confirmed" is a wide concept. It is rather difficult to describe this term with some limits but it includes not only the environment, but also health and welfare, education, social justice, culture and economic livelihood.

If an activity, a work or a process can be continued preserving its bio-diversity and natural ecosystems today and also in the future, it is considered sustainable. Every nation thinks of how the decisions we make today will affect the next generations as a sustainability problem. Our decisions that are decreasing and wasting the natural resources above the regenerative capacity of the earth can cause next generations to have less joy of the world than we do now. Besides, climate changes are defined as the biggest problem today. The reason of danger of climate change is said to be the unsustainable way we have been using the world. We can say, we exploit the natural resources and environment and they are not important to us much.

In December 1983, the UN General Assembly realized that there was a heavy deterioration of the human environment and natural resources, and in order to rally countries to work and pursue sustainable development together, the UN decided to establish the Brundtland Commission. Formally known as the World Commission on Environment and Development (WCED), the Brundtland Commission's mission was to unite countries to pursue sustainable development together. This commission prepared a report called as "Our Common Future" in October 1987, also known as the Brundtland Report. This document coined and defined the meaning of the term "Sustainable Development" as "development that meets the needs of the present without compromising the ability 
of future generations to meet their needs." The focus is such that the perspectives of society and nature are equal to that of economy. With this definition sustainability emphasizes that economy and society are part of a closed system (Wikipedia.org, 2015).

All human activities are limited with the nature. We need to balance the idea of "having a good life" and the limits of nature to which it will allow us. Moreover, the relation between our welfare, environmental protection, and economic development must be arranged in order not to violate the rights of the next generations. Sustainability is interpreted as the struggle for balance between a good life and the integrity of nature, and already human actions have had such an impact that 'the good life' goes beyond the earth's environmental limits and have upset the integrity of nature (Unv. of Iceland, 2012).

As University of Iceland's Sustainability and Environmental Policy document indicates "It means growth cannot extend beyond the definite limits of nature. Resources in the globe are limited and the ability of the environment to maintain vital processes is easily disrupted. It is generally accepted that the current path of humanity bears clear signs of unsustainability. People's ideas in the more wealthy parts of the world about 'the good life' have led to consumption far beyond what the earth can support. While part of humankind uses the earth's resources in excess, others get less than their share" (Unv.of Iceland, 2012).

Our world is smaller now, everyone can learn about everything quickly and find out what nation or economy causes damage to the earth in what sizes. The unsustainable technological developments created by some economies to provide its citizens with a good life in prosperity beyond natural limits and the damage they cause to our ecosystem has reached a threatening size and it threatens the life of the next generations which are also the future of these nations. Activities held by national and international non-governmental organizations like TEMA, and Green Peace are very important in order to inform the public, keep them in solidarity, and raise awareness. To create a sustainability movement that is integrated to the world like TEMA can only be accomplished by having educational programs with the purpose of educating individuals into being organized against national global issues. The education individuals receive in schools must show that personal and social responsibilities are not only limited to the place they live. For a sustainable life, a sustainable ecosystem and a sustainable development are needed.

The cultural structure and education which are needed for maintaining an eligible life and sustainable future are argued as connected pieces of this phenomenon. However, for all of these a culture of sustainable life is needed and therefore a sustainable education system is needed which can give this to individuals and society. Countries' economic and social development being sustainable, preventing global climate changes and natural disasters are directly proportionate to education strategies' involving sustainability.

\section{Sustainability Education}

Sustainability education is a model that aims to support the learners to become responsible citizens who struggle for a more sustainable world with their knowledge, skills, values and mental abilities. This model is not a receipt that offers 'the right' application list which is relative with learning output. Instead, it is a list of repetitive questions and answers which demands students to find solutions about unsustainable situations. Therefore, sustainability education provides a discovery process as well as a vision for the future.

Sustainability education is not only a basic series of knowledge. However no one can include a system approach to the natural and social worlds without understanding how it works. According to this, sustainability education must present the basic understanding of art, science and social sciences. 
Sustainability training also emphasizes the problem solving skills which are essential for a systems approach. This helps students to improve their ability to assess experimental results and examinations, to think creatively about alternative views, communicate orally and in a written way, liaise with political rhetoric and to develop the ability to propose and defend actions. More importantly, sustainability education serves as condenser which teaches us how to solve and understand the problems. Sustainability education promotes seeing the relations between social and ecological systems and understanding the complexity of our world. While improving students' interests in crosscultural perspectives and global interactions, this model also takes giving importance to their own community into consideration (Luther College, 2015).

\section{UNESCO and Education for Sustainable Development (ESD)}

The United Nations started "Education for Sustainable Development" action through UNESCO in 2004. The main objective of this action is to inform every individual with access to education about using natural sources and realization of a sustainable lifestyle. In this way it is aimed to realize a longterm social transformation.

UNESCO indicates that "Education for Sustainable Development" allows every human being to acquire the knowledge, skills, attitudes and values necessary to shape a sustainable future. ESD means including key sustainable development issues into teaching and learning; for example, climate change, disaster risk reduction, biodiversity, poverty reduction, and sustainable consumption.

It also requires participatory teaching and learning methods that motivate and empower learners to change their behavior and take action for sustainable development. ESD consequently promotes competencies like "critical thinking", "imagining future scenarios" and "making decisions" in a collaborative way. ESD requires far-reaching changes in the way education is often practiced today (UNESCO, 2015).

\section{Eco-schools Program in Turkey}

The closing meeting of the 10 years of ESD action; "Education for Sustainable Development UNESCO World Conference" took place on in 2014 in Nagoya, Japan. In this conference, all the studies UNESCO member states held, successful applications, problems and negotiations about what could be done in the future were held.

Turkish Environment Education Foundation (TÜRÇEV) is another NGO that was founded in 1993 in order to start Blue Flag beach in our country to certify clean seaside. This organization also carries out "ESD Program" with Ministry of National Education, Ministry of Environment and Urbanization, and UNESCO Turkish National Commission. TÜRÇEV's Eco-schools Program is implemented in pre-school education institutions and elementary schools to provide training for environmental awareness, environmental management and sustainable development (Fig.2). This program motivates students to reduce the environmental effects of schools to help sustainable development process be carried out at a local level. Thus, eco-schools provide rest of the society with environmental awareness by going beyond the instructor in classrooms. 

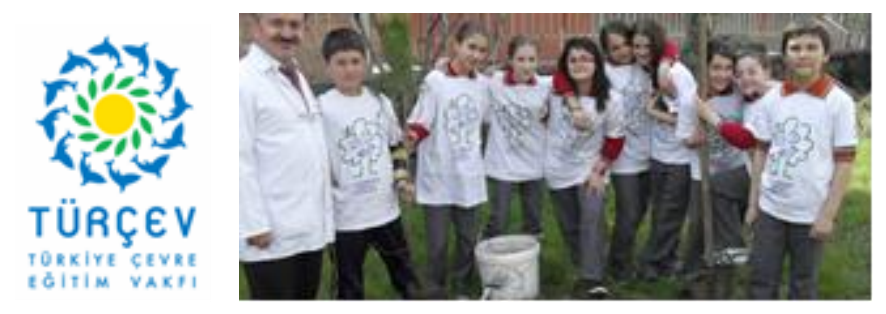

Fig.2. TÜRÇEV and its "Eco-schools Program" in Turkey.

In addition to providing schools with a leading environmental education program, Eco-schools program has the feature of a reward plan as it gives Green Flag Award to the schools with outstanding achievements in their activities and the environment education they have given. Green Flag Award is an eco-tag symbolizing an internationally known, respected and environmentally-friendly school. The validity period of the award is two years; hence it needs to be renewed every two years.

\section{Arts and Design Education for Sustainable Development}

UNESCO's ESD action takes place in school programs through arts and design education with the aim of reaching competencies such as "critical thinking", "imagining future scenarios" and "making decisions". It is beneficial to point out how ten art education goals set by a respected educator, Elliot Eisner in art and design education field match with UNESCO's competencies.

\section{Lessons the Arts Teach}

1. The arts teach children to make good judgments about qualitative relationships. Unlike much of the curriculum in which correct answers and rules prevail, in the arts, it is judgment rather than rules that prevail.

2. The arts teach children that problems can have more than one solution and that questions can have more than one answer.

3. The arts celebrate multiple perspectives. One of their large lessons is that there are many ways to see and interpret the world.

4. The arts teach children that in complex forms of problem solving purposes are seldom fixed, but change with circumstance and opportunity. Learning in the arts requires the ability and a willingness to surrender to the unanticipated possibilities of the work as it unfolds.

5. The arts make vivid the fact that neither words in their literal form nor numbers exhaust what we can know. The limits of our language do not define the limits of our cognition.

6. The arts teach students that small differences can have large effects. The arts traffic in subtleties.

7. The arts teach students to think through and within a material. All art forms employ some means through which images become real.

8. The arts help children learn to say what cannot be said. When children are invited to disclose what a work of art helps them feel, they must reach into their poetic capacities to find the words that will do the job.

9. The arts enable us to have experience we can have from no other source and through such experience to discover the range and variety of what we are capable of feeling. 
10. The arts' position in the school curriculum symbolizes to the young what adults believe is important.

Eisner's these 10 goals are manly used in the art and design curricula of the schools in many countries of the world (Eisner, 2002).

The Bonn declaration (2009) states that:

"The challenges arise from values that have created unsustainable societies... We need a shared commitment to education that empowers people for change. Such education should be of a quality that provides the values, knowledge, skills and competencies for sustainable living and participation in society."

Art education plays an important role in an integrated approach to global issues concerning sustainability. An artistic approach in education could create a platform for students to reflect on their daily activities in profound and critical ways. This could help them focus on taking personal responsibility and on internal changes that become a starting point for change in their external environment. To create the foundations for the good life one needs to foster many different qualities as well as understand how they interact with one another (Macdonald, 2014).

Art and Design education has a multi-directional content for sustainable development ideals. Aesthetic sensitivity and critical thinking which are in the nature of art and design fields, help students grow as individuals who are environment and ecosystem-sensitive.

Sustainability of art and design education also can be seen in two-directions. The first side is to keep students away from any kind of violence by providing them with sensitivity and empathy as well as help them develop respect for society and environment. In this way, students gain susceptibility and eagerness to protect ecosystem and live in the limits of nature (Özsoy, 2014). The second side is the sustainability projects carried out by students and instructors in art and design lessons. These are applications especially to clarify that a sustainable environment, nature and ecosystem is important for a sustainable life. Now, I would like to show some examples about the second side.

\section{Some remarkable applications}

These four examples of the sustainability and art and design education below will help to be understood the issue more clearly.

\subsection{Time Capsule: To preserve something that should not be lost in the future.}

First example is Time Capsule (see Fig.3). Guðrún has taught at the elementary school level for eighteen years in Iceland. She created a project for her 4th and 5th graders that she called Time Capsule to be exhibited at a conference for art educators. When her students started the project they were aware that the project would get public exposure. This produced feelings of anticipation and showed them how they could effect change outside their classroom.
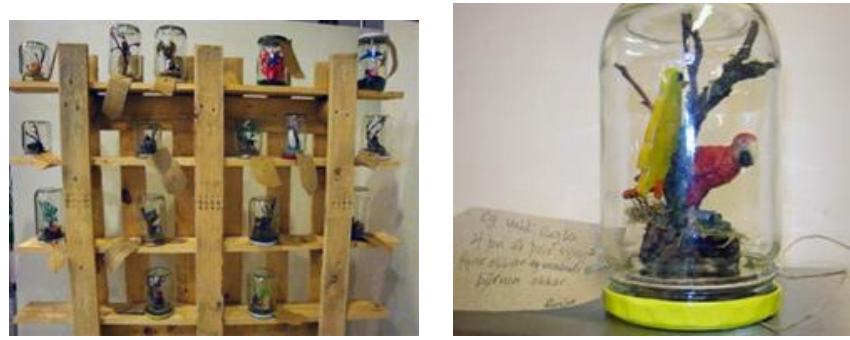

Fig.3. Two examples from the Time Capsule Project. 
In Time Capsule, fourth and fifth graders created small artworks that fitted into glass jars. The jars were then arranged so that they presented a unified whole. The theme of the project was to preserve something that should not be lost in the future. The children's choices showed what they held dear, such as animals, plants, or a memory. They inserted their work into a jar and attached a small note that explained their choice.

The aim of Guðrún's project was to spark critical thinking and examine values. It also valued different points of view, embracing diversity of thought and experiences. By exhibiting the work, the aim was also to empower students as active citizens by participating in a project which generates hope. She indicates that "It was incredibly successful and fun because it inspired them to think about sustainability from a more emotional standpoint."

Guðrún mentions that the arts can give students an opportunity for self-evaluation. This is connected to developing the attribute of humility, "to be able to exhibit their work and say, yes, I worked hard on this and I'm content with it. Some students have reached that developmental milestone, but others think it will all happen of its own accord and that one does not have to work hard at anything" (Macdonald, 2014).

\subsection{Cafè Heimdal}

Second example is "Cafè Heimdal". With the attempts of a Danish artist and designer Kenneth A. Balfelt, a micro urban renewal project carried out in a region in Copenhagen in 2006. 10 grade pupils renew old local pub. This public art project examined the wishes and ideas of the local residents. For this Balfelt invited pupils from a local school to make an interior design renewal at a local pub with regular customers (see Fig.4). He usually carries out his work where Danish immigrants and unemployed people live. Artist's main purpose is to bring two different groups of local people who do not have a good relationship with one another. These included some unemployed, alcoholic Danish men and children of immigrant families who were going to the school next to the cafe.
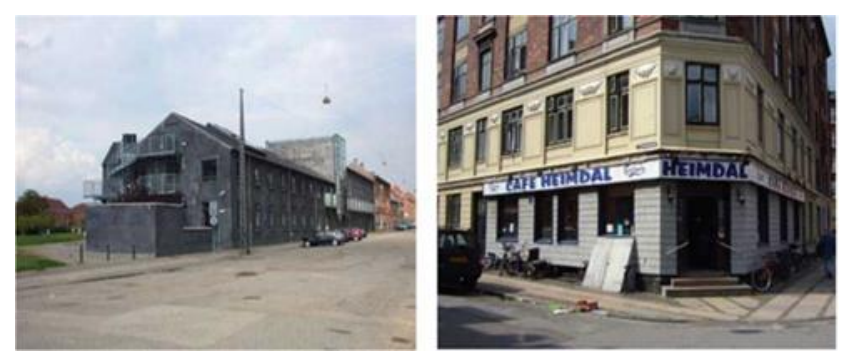

Fig.4. The HGO School and Cafè Heimdal.

Together with the designer, the boys designed a model in Douglas fir with mahogany cut-out letters and presented it to the owner and the costumers. The model was approved, and the new sign is now a permanent reality that can be seen and sensed by pub-guests, school pupils and all other inhabitants and guests within the quarter. 

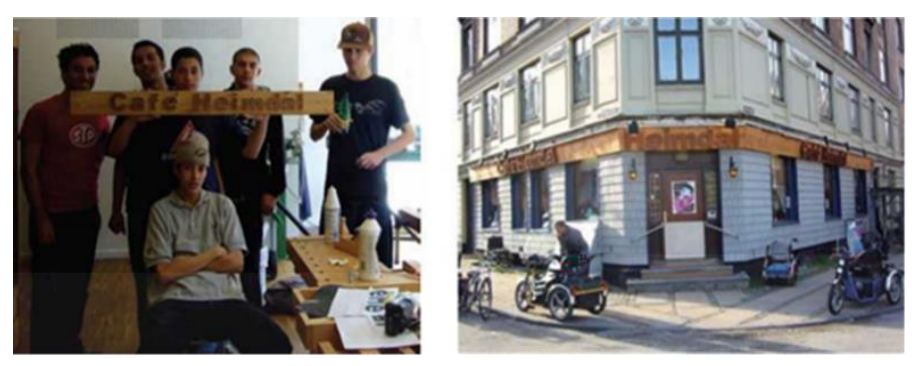

Fig.5. The new sign for Cafe Heimdal - prototype and final result. (Copyright/courtesy and photo: Kenneth A. Balfelt).

When it is analyzed in sustainable environment context, this design-based project is a good example of how two groups who are from different cultural and social background and different ages are related to each other with no prejudice. Designer Balfet not only made a research but also made two things clear: daily lives and environments of these opposite groups. Illeris indicates in her paper that Cafè Heimdal tells about the potential of art education to work within social and political situations 'on location' and 'for real'. "As an art project with a clear educational dimension", she says, "it also tells me that there might be a way into environmental sustainability through staging what I have chosen to call 'performative experimental communities' (Illeris, 2012)."

\subsection{Lessons learned from the landscape}

Fourth remarkable example is a research project by Kathy Miraglia and Cathy Smilan from the USA. "Lessons learned from the landscape: an integrated approach."

This research project and its application presents a multidisciplinary pedagogy that integrates art education and ecological studies toward the goal of fostering affection for the landscape. This approach to designing art curriculum was based on ecological and outdoor education Expeditionary Principles.

Miraglia and Smilan implemented this project with 12 female art teachers aged between 20 and 50 in 2006. They also carried out a performance of the course they had taught to the instructors under the name of "Interconnections: A Multidisciplinary Approach to Art Education" in University of Massachusetts Dartmouth. The practice was carried out in a garden of an elementary school close to the university (Fig.6).

The teachers spent an intensive on-site week working in the landscape, nature trail walking, camping, journaling, observing, collecting, creating, and problem solving, challenging themselves and seeking adventures. The purpose of this multidisciplinary course was to encourage affection for the environment through exploration of the landscape and the use of natural materials to create art, starting with personal experience and moving to classroom implications and applications. 

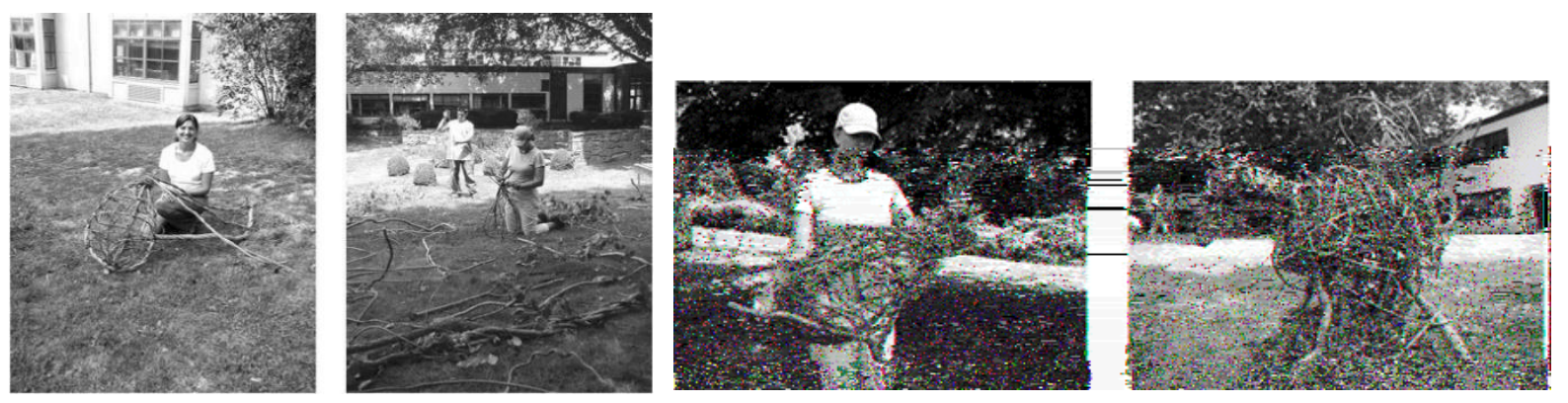

Fig. 6. Tear-drop shaped and construction vine sculptures.

The course work required participants to implement outdoor education principles and adapt them to art education as tools for problem solving, building confidence and building trust between teachers, students and peers. The course required teacher participants to design curricula that made multidisciplinary connections and included cultural perspectives of the natural world.

From teaching this course, the researchers found that "going beyond the classroom, being situated in the landscape, observing and interpreting nature through art forms, and creating authentic learning opportunities in context promotes appreciation for the environment."

This project showed that a learning activity could start in a classroom and move to a schoolyard where there is a microcosm of the landscape. One of the participant teacher points out that "Through these experiences, we also become aware of how we ourselves are part of the web of life, and over time the experience of ecology in nature gives us a sense of place. We become aware of how we are embedded in an ecosystem; in a landscape with particular flora and fauna; in a particular social system and culture." (Miraglia \& Smilan, 2009).

\subsection{Altered viewscapes: Raising awareness through creative practice in the urban cultural heritage of Istanbul}

Third application is from Turkey. The 'Altered Viewscapes of Istanbul Project', conducted in spring 2012 by Ilgım Veryeri Alaca and Lucienne Thys-Şenocak from Koç University in İstanbul (Fig.7). The purpose of this project was to introduce university students to different issues and interpretations of cultural heritage, and to foster an involvement in urban heritage through creative practice. The project was multidisciplinary and conducted during ten weeks of the semester in a course called Art and Innovation.

The project was a case study designed specifically to reflect on one of the many alterations in Istanbul's urban environment: the viewscapes of the historic peninsula. It sought to introduce an art educational model to connect students and their creative expressions to the cultural heritage of the city. Raising awareness among the students about both the rapid pace of development and their lack of agency in the urban changes occurring in Istanbul was also among the goals of the project.

By 2011 Istanbul's population was almost fourteen million with an annual growth rate of 27 per cent. This growth, much of it the result of rural to urban migration, has dramatically increased the pressure on the urban fabric of this historic mega-city and poses a threat to the cultural heritage of the historical peninsula of Istanbul, a World Heritage site since 1985 . Equally alarming is the transformation of the historic silhouette of the peninsula. Even though the World Heritage Organization recognized in 2011 Istanbul's silhouette as an essential element of the city's authentic 
urban heritage - a trademark that may be viewed on many souvenirs, including tee-shirts sold in the bazaars of the historic quarter and elsewhere, it is now at risk.
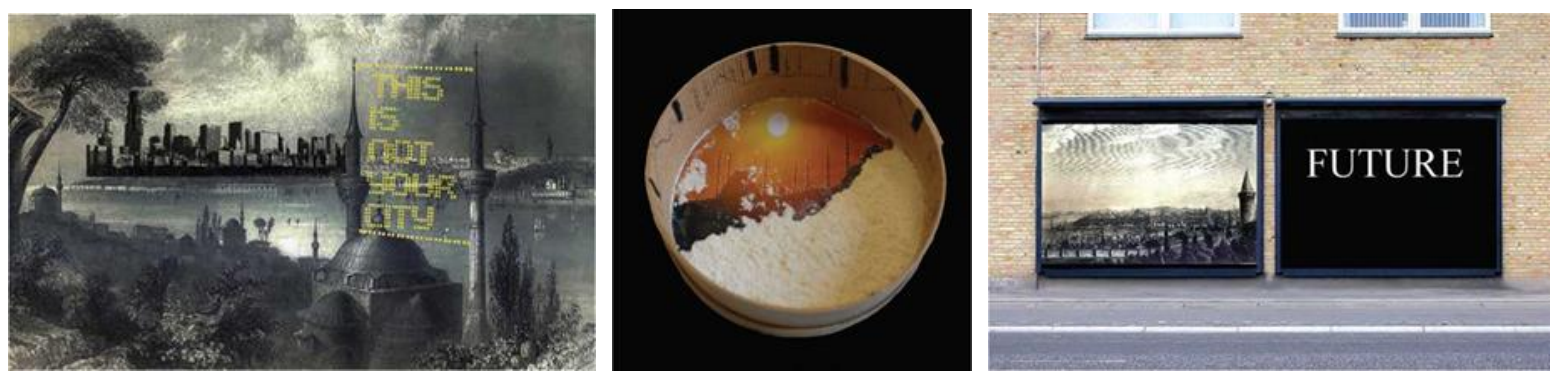

Fig. 7. Three artworks from the project.

According to UNESCO,'The setting and distinctive skyline of the historic peninsula continues to express the outstanding universal value of the property. However, the ongoing ability of the wider maritime setting to do this depends on ensuring that development does not compromise views of the skyline'(Veryeri Alaca and Thys-Şenocak, 2015).

The project enabled students to evaluate their relationships to selected cultural heritage sites of the city and asked them to consider how this heritage could foster creative forms of civic participation. The students were asked to reflect on the aesthetic experience of viewing the historic peninsula of Istanbul and particularly, Eminönü, one of the city's oldest districts. Students drew connections between the creative process and active spectatorship of the viewscape while considering how social, political and economic factors shape public space and the urban environment.

Lastly the art processes followed in the 'Altered Viewscapes of Istanbul Project' helped students to question their own identity while raising their awareness and commitment to the heritage, culture and urban environment of their city (Veryeri Alaca and Thys-Senocak, 2015).

\section{Conclusion}

Competencies like "critical thinking", "imagining future scenarios" and "making decisions" which are foreseen by UNESCO's Education for Sustainable Development Project are the basic goals in art's and design's nature thus they create the essence of art and design education curriculum.

Critical art and design education aims to change. It deeply criticizes the existing systems and habits by defending a more humanist, respectful and compatible ways to live for all societies on earth. Critical approach sees education as converter. It foresees instructors' and students' journey to an unknown life and ways of thinking, not an education in existing information and projects or an education of imitation. Critical art and design education wants people to be seen not as individuals only but as a group before anything else. For that reason, critical art and design education sees people as responsible individuals who value society's today and future needs before their own personal benefits. Critical education wants individuals who are promised to have a better life by economic systems to care about how much importance to nature's limits and environment sensitivity are minded.

Art and design education offers the best environment for individuals to dream about having a good future. It makes it easier to dream of a world with countries where there is no war and they live in peace and serenity, all natural sources are shared equally in their own limits. 
Özsoy, V. (2016). Arts and Design Education for Sustainable Development, Global Journal on Humanites \& Social Sciences. [Online]. 03, pp 487-497. Available from: http://sproc.org/ojs/index.php/pntsbs

Art and design education ensures people to respect diversities, by developing sensitivity to environment and to cooperate with others in their decisions. Moreover, it helps people care for their future for a sustainable development ideal that is nature-friendly and respects ecosystem.

Art and design education helps people raise away from violence and vandalism, develop empathy and respect for cultural and social diversity.

In fact contributions of art and design in individuals' education provide sustainability in human education which is the main source of a sustainable development.

Finally it will be valuable to conclude the paper with these sayings of three thinkers:

"Polluted environment pollutes the human soul, and the polluted souls pollute the environment." (Aziz Nesin-Famous Turkish writer).

"The world is enough to provide for everyone's needs, but is unable to provide for everyone's greed." (Mahathma Gandhi)

"Nature is not an estate we inherited from our grandparents, but is a trust we will leave behind for our grandchildren." Seattle, Chief of Duwanish Native Americans.

\section{References}

Brundtland Commission. Retrieved in 11 June 2015 from Wikipedia: http://www.bneportal.de/fileadmin/unesco/de/Downloads/Hintergrundmaterial international/Brundtlandbericht.File.pd f?linklisted $=2812$

Café Heimdal, Kenneth A. Balfelt, Received June 17, 2015 from: http://kennethbalfelt.org/cafe-heimdal/

Eisner, E. (2002). What the Arts Teach and How It Shows. The Arts and the Creation of Mind, In Chapter 4, (pp. 70-92). Yale University Press. Available from NAEA Publications.

Received from: http://www.un-documents.net/wced-ocf.htm

Received from: https://en.wikipedia.org/wiki/Brundtland Commission

Illeris H. (2012). 'Interrogations: Art, art education and environmental sustainability', International Journal of Education through, 8, 221-237

Luther College (2015). "Sustainability Education", 01.04.2015, Received April 01, 2014 from: http://www.luther.edu/sustainability/campus/education/faq/

Macdonald, A. (2014). Human nature and participatory virtues in art education for sustainability. Relate North 2014, Art, Heritage and Identity. University of Lapland Press.

Miraglia, K. and Smilan, C. (2009). "Lessons learned from the landscape: an integrated approach" International Journal of Education through Art, Volume 5, Numbers 2 and 3. pp. 169-185 Intellect Ltd.

Özsoy, V. (2015). Görsel Sanatlar Eğitimi, (Visual Arts Education): Resim-İ̧̧ Eğitiminin Tarihsel ve Düşünsel Temelleri, (3. Baskı), Ankara: Pegem Akademi Yay.

The Bonn declaration, world conference on education for sustainable development, (2009). Bonn, Germany. 15.04. 2015, From: http://www.esd-world-conference2009.org/en/whatsnew/newsdetail/item/\%20bonn-declaration-adopted.html .

TÜRÇEV: 13.05. 2015. http://www.xn--trev-1oa8j.org.tr/

UN (1987). Development and International Economic Co-ooperation: Environment, Report of the Comission on Environment and Development. Retrieved in 09 June 2015 from: http://www.un.org/documents/ga/res/42/ares42-187.htm

UN Report of the World Commission on Environment and Development: Our Common Future: 08.05 2015:

UNESCO Turkey. Sürdürülebilir Kalkınma İçin Eğitim. Retrieved in 27 March 2015 from: http://www.unesco.org.tr/?page=3:70:2:turkce

UNESCO. $\quad$ Education for Sustainable Development http://www.csb.gov.tr/gm/egitim/index.php?Sayfa=haberdetay\&ld=16735

UNESCO. Education for Sustainable Development (ESD). Retrieved in 27 March 2015 from: http://www.unesco.org/new/en/education/themes/leading-the-international-agenda/education-forsustainable-development/

University of Iceland. (2012). Sustainability and environmental policy. Retrieved in June 2015 from: http://english.hi.is/files/thb/english ui sustainability and environmental policy.pdf

Veryeri Alaca, I. and Thys-Senocak, L. (2015), 'Altered viewscapes: Raising awareness through creative practice in the urban cultural heritage of Istanbul', International Journal of Education through Art 11: 1, pp. 21-41

World Alliance for Arts Education - WAAE, 15.04.2015 http://m2.edcp.educ.ubc.ca/waae/ 